\title{
Tonic pupil in leprosy
}

\section{Pupila tônica em doença de Hansen}

Marco Aurélıo Lana-Peixoto ${ }^{1}$, Wesley Ribeiro Campos $^{1}$, Pedro Augusto Costa Reis ${ }^{1}$, Christian Marcellus Camargo Campos $^{1}$, Carlos Alberto Rodrigues ${ }^{2}$

\begin{abstract}
Pupil abnormalities in leprosy usually result from chronic iritis with loss of stroma, iris miosis, a sluggish reaction to light, and poor dilation in response to anticholinergic mydriatics. We report two patients with long-standing lepromatous leprosy who developed tonic pupils characterized by mydriasis, absence of reaction to light and hypersensitivity to weak cholinergic solution. Examination revealed iritis and iris atrophy. In both cases, instillation of dilute $0.1 \%$ pilocarpine caused miosis in the affected eyes. Tonic pupil occurs in many conditions, but its association with leprosy had not been previously reported.
\end{abstract}

Keywords:Tonic pupil; Mydriasis; Leprosy; Iritis; Iris/injuries; Atrophy; Case reports

\section{RESUMO}

Anormalidades da pupila em pacientes com doença de Hansen, ocorrem mais comumente devido a irite crônica com perda do estroma iriano, miose, diminuição da reação à luz, e dificuldade de dilatação em resposta a colírios anticolinérgicos. Relatamos dois pacientes com doença de Hansen na forma lepromatosa que desenvolveram pupilas tônicas, caracterizadas por midríase, ausência de reação a luz e para perto e hipersensibilidade a fraca concentração de solução colinérgica. O exame revelou irite e atrofia iriana. Em ambos os casos a instilação de pilocarpina $0,1 \%$ causou miose nos ol hos afetados. A pupila tônica tem sido relatada em muitas condições, mas sua associação com doença de Hansen ainda não havia sido descrita.

Descritores: Pupila tônica; Midríase; Hanseníase; Irite; Iris/lesões; Atrofia; Relato de casos

\section{INTRODUCTION}

Pupil abnormalities are common in patients with leprosy ${ }^{(1-4)}$. Characteristically, the pupils show persistent miosis, sluggish reaction to light, and poor dilation in response to anticholinergic mydriatics. They are usually associated with chronic iritis and iris atrophy, loss of iris stroma and development of synechiae as well as corneal and lenticular changes that cause visual loss. These changes have been ascribed to postganglionic sympathetic denervation of the dilator muscle cells $s^{(1)}$

We report two patients with leprosy who presented unexpected pupillary features of tonic pupil, such as mydriasis, abolished reaction to light, exaggerated miosis during accommodation, and a hypersensitive reaction to weak cholinergic solutions ${ }^{(5,6)}$. To the best of our knowledge, tonic pupils had not been previously described in leprosy.

\section{CASE REPORTS}

\section{CASE 1}

A 33-year-old white woman with lepromatous leprosy for 10 years was referred for neuro-ophthalmological evaluation due to a 1-year history of intermittent anisocoria. She stated that on awakening in the mornings, she frequently noticed that her left pupil was dilated but decreased in size during the course of the day, usually reaching symmetry with the right pupil in the late afternoon. She had completed the WHO-recommended antileprosy multidrug therapy (MDT).

Ophthalmic examination revealed a corrected visual acuity at a distance of 20/20 OU. Slit-lamp biomicroscopy was unremarka- ble and the intraocular pressure was $10 \mathrm{mmHg}$ OU. In dim light, the right pupil measured $3 \mathrm{~mm}$ and the left pupil $5 \mathrm{~mm}$. The left pupil showed neither direct nor consensual reaction to light and did not constrict on immediate attempted accommodation. The right pupil constricted to near vision and to light. After instillation of a drop of dilute $0.1 \%$ pilocarpine $\mathrm{OU}$, the right pupil showed no constriction, whereas the left pupil constricted to $1 \mathrm{~mm}$ in diameter. The rest of the examination was negative.

\section{CAse 2}

A 42-year-old black woman with lepromatous leprosy for 22 years was examined because of anisocoria associated with diffuse episcleritis in both eyes. She had experienced recurring anterior uveitis in both eyes and had been treated with MDT for five years associated with intermittent courses of oral prednisone.

On examination the visual acuity was 20/20 OD and 20/20 OS. Slit-lamp biomicroscopy disclosed evidence of diffuse scleritis OU. Ophthalmoscopy was unrevealing. The right pupil measured $6 \mathrm{~mm}$ in diameter and did not react to light or accommodation. The left pupil was $3 \mathrm{~mm}$ in diameter and showed normal constriction to light and near vision. Thirty minutes after instillation of pilocarpine $0.1 \%$, the right pupil constricted to $1 \mathrm{~mm}$ whereas the left pupil remained unchanged. One month later the patient noticed that her left pupil was also dilated. The right pupil measured $7 \mathrm{~mm}$ in diameter and the left pupil $6 \mathrm{~mm}$. Neither pupil constricted to light or attempted accommodation. Instillation of pilocarpine $0.1 \%$ provoked a remarkable miosis bilaterally (Figures 1-4). The patient was again put on steroids and anti-leprosy drugs. 


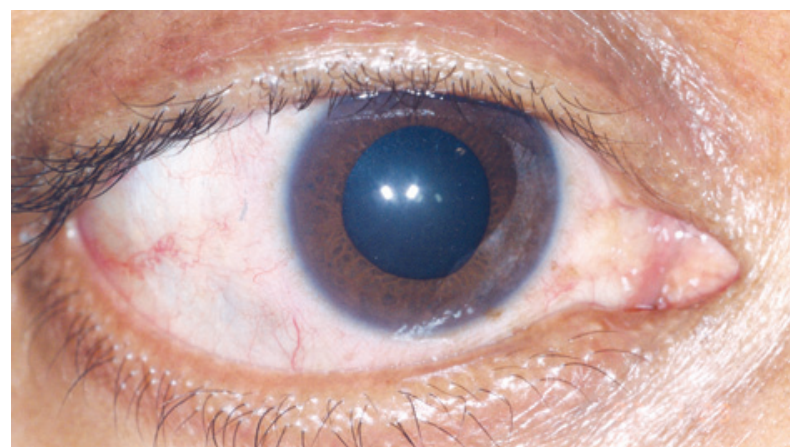

Figure 1. Right eye before instillation of dilute $0.1 \%$ pilocarpine (Case 2 ).

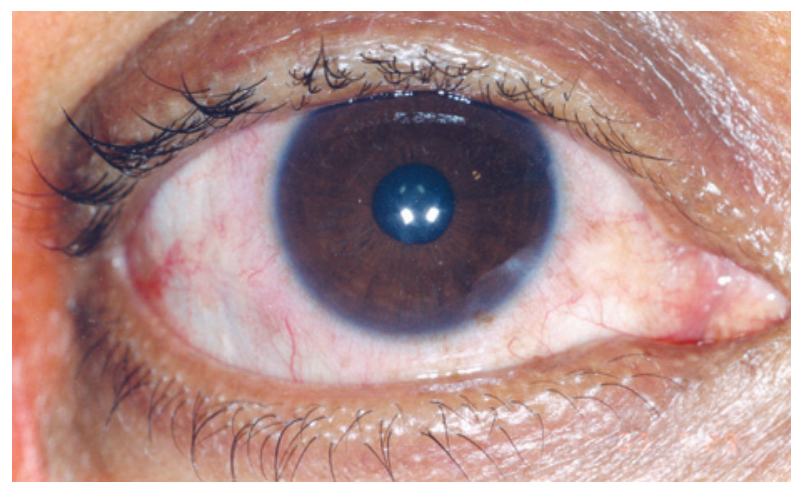

Figure 2. Right eye after instillation of dilute $0.1 \%$ pilocarpine (Case 2).

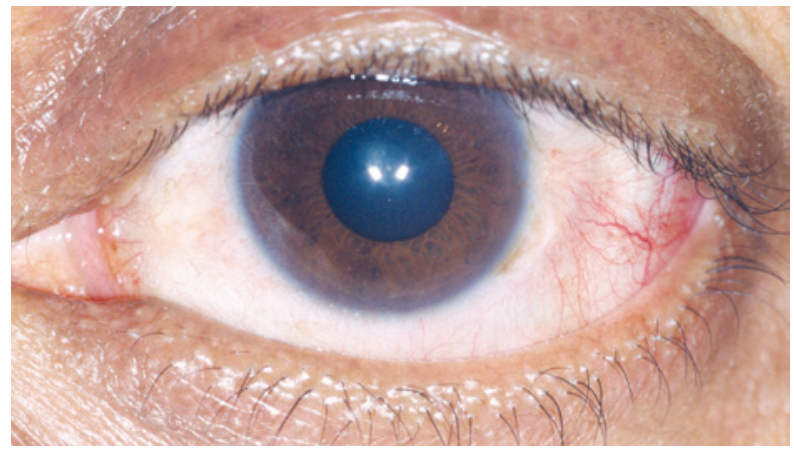

Figure 3. Left eye before instillation of dilute $0.1 \%$ pilocarpine (Case 2).

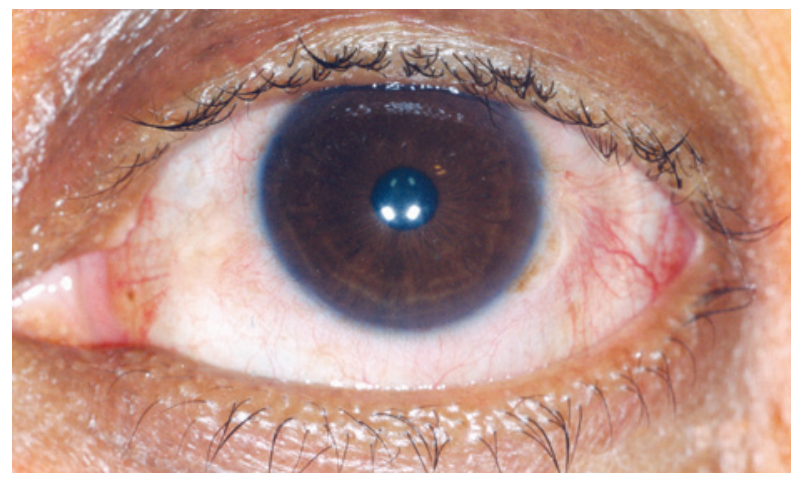

Figure 4. Left eye after instillation of dilute $0.1 \%$ pilocarpine (Case 2 ).

\section{DISCUSSION}

Leprosy (Hansen's disease) is a chronic granulomatous condition that is still highly prevalent in very poor populations in Asia, Africa and Latin America ${ }^{(7)}$. Iris changes in leprosy are common and may occur either as a hypersensitivity reaction or as a result of direct bacterial invasion of the iris and its innervation. In lepromatous leprosy, direct bacillary invasion of the tissues takes place insidiously and chronic iritis results from direct involvement of the iris and ciliary body. In later stages of the disease, changes in the iris stroma with ensuing atrophy and synechiae in association with miosis develop $p^{(1,2,8,9)}$.

In lepromatous leprosy, chronic iritis with progressive iris atrophy is considered not as a true inflammation, but rather as a neuroparalytic condition that results from autonomic denervation of the iris ${ }^{(8)}$. It is well-known that the iris contains, in addition to sensory nerve fibers, small nonmyelinated sympathetic and parasympathetic nerve fibers intimately related to cells of the dilator and sphincter pupillae muscles ${ }^{(10)}$. Deprivation of the autonomic supply of the iris muscles is responsible for the increasingly sluggish and miotic pupils and the poor reaction to non-sympathomimetic mydriatics as well as the premature presbyopia observed in apparently normal patients ${ }^{(9,10)}$.

Evidence supporting the role of sympathetic postganglionic denervation has been pharmacologically demonstrated by the hypersensitivity response following the instillation of very weak concentrations of epinephrine ${ }^{(4)}$. The frequent observation of the presence of lepromatous infiltrates within the iris and the absence of nerve lesions in areas of higher temperature suggest that involvement of the sympathetic fibers occurs within the iris rather than in the long ciliary nerves, carotid plexus or superior cervical ganglion ${ }^{(4)}$.

The reason for the preferential involvement of the sympathetic autonomic function of the iris is not fully understood. Some authors ${ }^{(4,9)}$ have ascribed it to differences in size and distribution of the dilator and sphincter muscles, as the dilator muscle is more thinly spread throughout the iris. However, dilator muscle is not fully denervated as suggested by the preservation of the ciliospinal reflexes in these patients ${ }^{(5,6)}$.

In contrast, damage to the ciliary ganglion or postganglionic parasympathetic innervation of the intraocular muscles causes a well-established set of clinical signs, including slight to moderate mydriasis, poor or absent pupillary reaction to light, segmental contractions of the iris sphincter, slow and long-lasting contractions to near vision, and cholinergic hypersensitivity of the denervated muscles $s^{(5,6)}$. The tonicity and slowness of the pupillary movements are caused by aberrant reinnervation of the sphincter muscle. Pupils with these features are known as tonic pupils, and have been observed in otherwise healthy individuals as well as in association with local or widespread involvement of the autonomic nervous system ${ }^{(9)}$.

The present report demonstrates for the first time in the literature that tonic pupil may also result from leprosy. The reason for the preferential involvement of the short ciliary nerve fibers within the iris in our patients rather than denervation of the dilator muscle, as usually seen in lepromatous patients, remains to be clarified.

\section{REFERENCES}

1. Ffytche TJ. The eye and leprosy. Lepr Rev. 1981:52(2):111-9.

2. Choyce DP. The diagnosis and management of ocular leprosy. Br J Ophthalmol 1969; 53(4):217-23.

3. Wood DJ. Ocular leprosy. Br J Ophthalmol. 1925:9(1):1-4.

4. Swift TR, Bauschard FD. Pupillary reactions in lepromatous leprosy. Int J Lepr Other Mycobact Dis. 1972;40(2):142-8.

5. Thompson HS. Adie's syndrome: Some new observations. Trans Am Opthalmol Soc. 1977;75:587-626.

6. Loewenfeld IE, Thompson HS. The tonic pupil: a re-evaluation. Am J Ophthalmol. 1967 63(1):46-87.

7. WHO Expert Committee on Leprosy: WHO Health Organ Tech Rep Ser. 1988;(768):1-51

8. Slem G. Clinical studies in ocular leprosy. Am J Ophthalmol. 1971;71(1 Pt 2):431-4.

9. Ffytche TJ. Role of iris changes as a cause of blindness in lepromatous lepra. $\mathrm{Br}$ Ophthalmol. 1981;65(4):231-9.

10. Last RJ. Wolff's Anatomy of the eye and orbit. $6^{\text {th }}$ ed. London: Lewis;1968. 